\title{
GROWTH CURVES OF Leishmania braziliensis braziliensis PROMASTIGOTES AND SURFACE ANTIGEN EXPRESSION BEFORE AND AFTER ADAPTATION TO SCHNEIDER'S DROSOPHILA MEDIUM AS ASSESSED BY ANTI-Leishmania HUMAN SERA.
}

\section{SUMMARY}

Leishmania braziliensis braziliensis(MHOM/BR/75/M2903) was grown in Schneider's Drosophila medium. In one set of experiments promastigotes were already adapted to the medium by means of serial passages whereas in the second cells were grown in a biphasic medium and transfered to the liquid. Growth was more abundant for culture medium-adapted cells; degenerate cells in small numbers as well as dead ones were present from day 5 for promastigotes adapted to liquid medium and from day 3 for newly adapted cells.

Synthesis of surface antigens differed according to length of cell culture as assessed by the titer of five mucocutaneous leishmaniasis sera on subsequent days. Five days of culture for cells already adapted to the culture medium and 3 days for newly adapted ones were judged to be the best for the preparation of immunofluorescence antigens.

KEY WORDS: Leishmania braziliensis braziliensis; Culture; Antigen.

\section{INTRODUCTION}

One of the characteristics of the "brazilien sis" complex of Leishmania is their fastidiousness to grow in liquid media ${ }^{4}$. Besides supporting parasite growth a culture medium must be also able to ensure conditions for a full expression of biochemical and immunological characteristics ${ }^{3}$. Recently, Schneider's Drosophila medium containing heat-inactivated fetal calf serum was considered to be have such characteristics regarding growth of Leishmania braziliensis braziliensis promastigotes ${ }^{8}$.

In this paper growth curves of L. b. braziliensis promastigotes were determined for cells already adapted to the liquid medium by repeated passages and for cells newly transfered from a biphasic medium (NNN) ${ }^{5,6}$. Immunofluorescence antigens were prepared from parasites recovered from the liquid medium and its performance was assessed by comparison of changes in serum titers and on parasite morphology with an antigen prepared with $\mathbf{L}$. major-like promastigotes.

\section{MATERIALS AND METHODS}

L. b. braziliensis (MHOM/BR/75/M2903) was grown in Schneider's Drosophila medium (SDM)

(1) Seroepidemiology Laboratory, Instituto de Medicina Tropical de Săo Paulo. Av. Dr. Enéas de Carvalho Aguiar, 470. CEP 05403 Sāo Paulo, SP., Brasil.

(2) Dept. Preventive Medicine, University of S. Paulo Medical School. 
CELESTE, B. J. \& GUIMARÄES, M. C. S. - Growth curves of Leishmania braziliensis braziliensis promastigotes and surface antigen expression before and after adaptation to Schneider's drosophila medium as assessed by anti. Leishmania human sera. Rev. Inst. Med. trop. Sāo Paulo, 30 (2): 63-67, 1988

supplemented with $20 \%$ fetal calf serum (SDM $+20 \%)^{3}, 8$; medium was prepared by mix ing individual componentes ${ }^{2}$. Promastigotes at a concentration of $2 \times 10^{6}$ cells $/ \mathrm{ml}$ were placed in 5 tubes of medium containing each $5 \mathrm{ml}$ of $\mathrm{SDM}+20 \%$, and incubated at $25^{\circ} \mathrm{C}$; daily, an aliquote was taken from each tube, cells counted in a hemocytometer and the cell average determined for each day of the growth curve.

The L. b. b. strain is maintained in the laboratory by culture in NNN biphasic medium ${ }^{5,6}$ with an overlay of SDM $+20 \%)^{3}$. The liquid overlay of one culture tube was transfered to a similar tube of NNN medium and cultured for another 4 days after which the overlay was trans. fered to $15 \mathrm{ml}$ of SDM $+20 \%$ and cultured for 4 days at $25^{\circ} \mathrm{C}$ after which a sufficient amount of overlay was placed in each of 5 tubes and the final volume made up to $5 \mathrm{ml}$ of SDM $+20 \%$ (as to give a final concentration of $2 \times 10^{6}$ cells $/ \mathrm{ml}$ ) and cultured; daily an aliquote was taken from each tube, cells were counted in a hemocyto meter and the cell average determined for each day of the growth curve.

An antigen for immunofluorescence tests (IF) was prepared according to GUIMARÁES et. al., $1974^{1}$ from cells recovered from both culture procedures on days 0 through 11: cells were centrifuged, washed twice in phosphate buffered saline, $\mathrm{pH} 7.2$ (PBS), fixed overnight in $2 \%$ formaldehyde, washed twice in PBS and the pellet resuspended in enough saline as to allow 20-25 parasites per microscope field $(400 \mathrm{x})$.

L. major-like promastigotes (strain 49) were cultured in LIT medium for 6 days at $25^{\circ} \mathrm{C}{ }^{1}$ and IF antigens prepared as described above.

IF tests: sera from five mucocutaneous leishmaniasis patients, and a positive and a negative standard sera were diluted in PBS (starting dilution 1/10) and placed onto microscope slide areas where promastigotes grown for different days in each culture medium were fixed; incubation and washing times were the same used previously ${ }^{1}$. An anti-human IgG fluorescein isothiocyanate conjugate (BioLab-Mérieux, Brazil) was optimally diluted to ensure maximum reactivity by means of a block titration of serum and conjugate (optimal dilution 1/100). Tests were read in a Carl Zeiss fluorescent microscope (Oberkochen, W. Germany) at 400 magnifications with an oil immersion objective.

\section{RESULTS}

Growth for promastigotes adapted to SDM $+20 \%$ is shown in table 1 and figure 1a. After 2 days growth parasite number doubled, peak growth was reached after 8 days and cells were still motile; in day 2 cells were represented mostly by promastigotes and very few round body flagellate cells were seen; their number cells started to increase from day 5 on when many dead cells were also seen although promastigote's motility was not impaired; on day 6 promastigote motility started to decrease until day 9 when it ceased completely (figure 1).
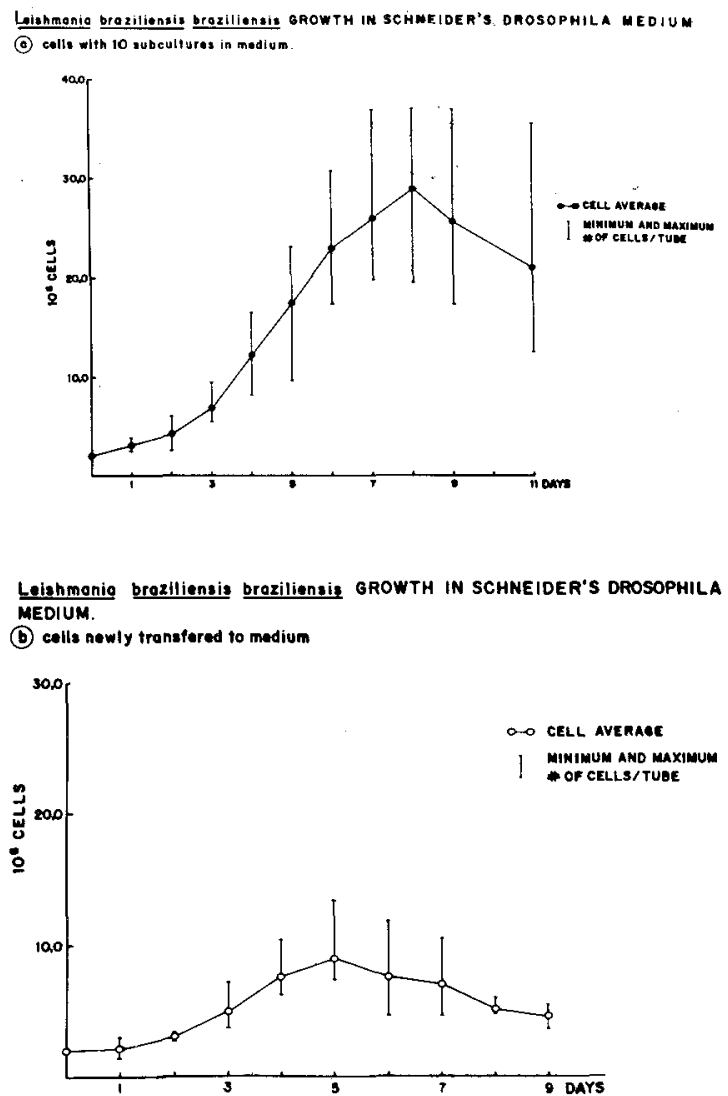

Fig. 1 - Growth of Leishmania braziliensis braziliensis in Schneider's Drosophila Medium: a - average and dispersion of cells with 10 subcultures in cuiture medium: b - average and dispersion of cells newly adapted to culture medium. 
CELESTE, B. J. \& GUIMARĀES, M. C. S. - Growth curves of Leishmania braziliensis braziliensis promastigotes and surface antigen expression before and after adaptation to Schneider's drosophila medium as assessed by antiLeishmania human sera. Rev. Inst. Med. trop. São Paulo, 30 (2): 63-67, 1988.

Growth of cells newly transfered to SDM + $20 \%$ only is shown in figure 1 . Cells started to grow after 2 days in culture and reached peak growth on day 5 ; on day 2 very few round body flagellates were seen and by day 4 they had greatly increased in number; on day 5 promastigotes showed little motility which practically ceased on day 6 .

Promastigotes showed a within-serum titer variation according to days of culture and to parasite adaptation to culture medium (table 2). Also, titers found with L.b.b. antigens were different from titers found with L. major-like antigen which were respectivelly, serum 1 - 160; serum 2- 20 ; serum 3-40; serum 4- 40; and, serum 5160. For some sera the highest titers were seen during log phase growth irrespective of cell adaptation to medium. The antigens prepared from cells grown for 5 days (for cells already adapted) and from cells grown for 3 days (for newly adapted cells) displayed a better resolution with all five sera than any other antigen, represented by a strong parasite membrane immunofluorescence and absence of inner structure non-specific immunofluorescence, resulting in a "cleaner" picture as judged from patterns in test sera as well as in control. After 9 and 11 days promastigotes no longer displayed any immunofluorescence; round cells displayed a strong staining.

\section{DISCUSSION}

The differences between growth of L.b.b. promastigotes adapted and newly transfered to SDM $+20 \%$ only were related to cell yield on one hand and to the expression of surface antigens on the other. For cells already adapted to SDM $+20 \%$ growth was very rapid (cells had doubled in number by day 2), was sustained for a longer period (peak growth was reached on day 8) and yielded 3 times more promastigotes than newly transfered cells (table 1, figure 1a). Growth was represented by promastigotes until day 2 when round body flagellate cells, less motile than promastigotes were noticed; their number increased sharply on day 6 as did dead cells indicating a relative incapacity of SDM supplemented with $20 \%$ fe tal calf serum to support cell growth. However, JAFFE et al., $1984^{3}$ consider this medium composition the most appropriate to culture L.b.b.
The same overall picture at a lesser magnitude was seen for cells transfered to SDM $+20 \%$ from NNN plus SDM overlay; round body flagellate cells were noticed on the second day of culture and their number increased sharply on day 4 , peak growth was reached on day 5 and no promastigote motility was noticed from day 6 on (table 1 , figure $1 b$ ).

The five mucocutaneous leishmaniasis sera were drawn from patients with the invasive stages of the disease. All patients were Montenegro positive and all patients had tissue sections indicative of leishmaniasis but parasites were no longer recovered from skin biopsies.

As seen from table 2 titers found using $\mathbf{L}$. major-like as antigen were different than the ones found with L.b.b. antigen regardless of adaptation to culture medium. Such differences could be as high as a 4-fold difference (serum 1 and 5, medium adapted cells; serum 2 and 4 , newly transfered cells); serum 3 however, was negative with all antigens prepared from medium-adapted cells and with antigens from newly-transfered cells in days 2,6 and 9 . Titer differences became less noticeable when cells had been cultured for some time, namely 5 days for medium-adapted cells and 3 days for newly-adapted ones, as for some sera titers reached a plateau (serum 1, 2, 5, medium-adapted cells) before becaming negative, on day 9 regardless of previous adaptation to culture medium.

As reported in the Results section, 5 days old promastigotes (for medium adapted cells) and 3 days old promastigotes (for newly transfered cells) yielded the best antigens for IF tests; also, the number of round body flagellate cells was not so high as to mask promastigote fluorescence since these cells show an intense body staining and when present in large numbers make impossible to assess a serum's titer as occurred in the last culture day irrespective of parasite adaptation to culture medium.

Until a larger body of evidence is collected regarding performance of $\mathbf{L}$. $\mathbf{b}$. braziliensis antigens in immunofluorescence tests whether cultured in liquid medium or not, L. major-like antigens will remain the chosen species for such tests. 
CELESTE, B. J. \& GUIMARÃES, M. C. S. - Growth curves of Leishmania braziliensis braziliensis promastigotes and surface antigen expression before and after adaptation to Schneider's drosophila medium as assessed by antiLeishmania human sera. Rev. Inst. Med. trop. São Paulo, 30 (2): 63-67, 1988.

TABLE 1

Growth curves of Leishmania braziliensis braziliensis promastigotes. Cell number and cell average for flagellates with 10 subcultures in Schneider's Drosophila medium and for newly transfered flagellates.

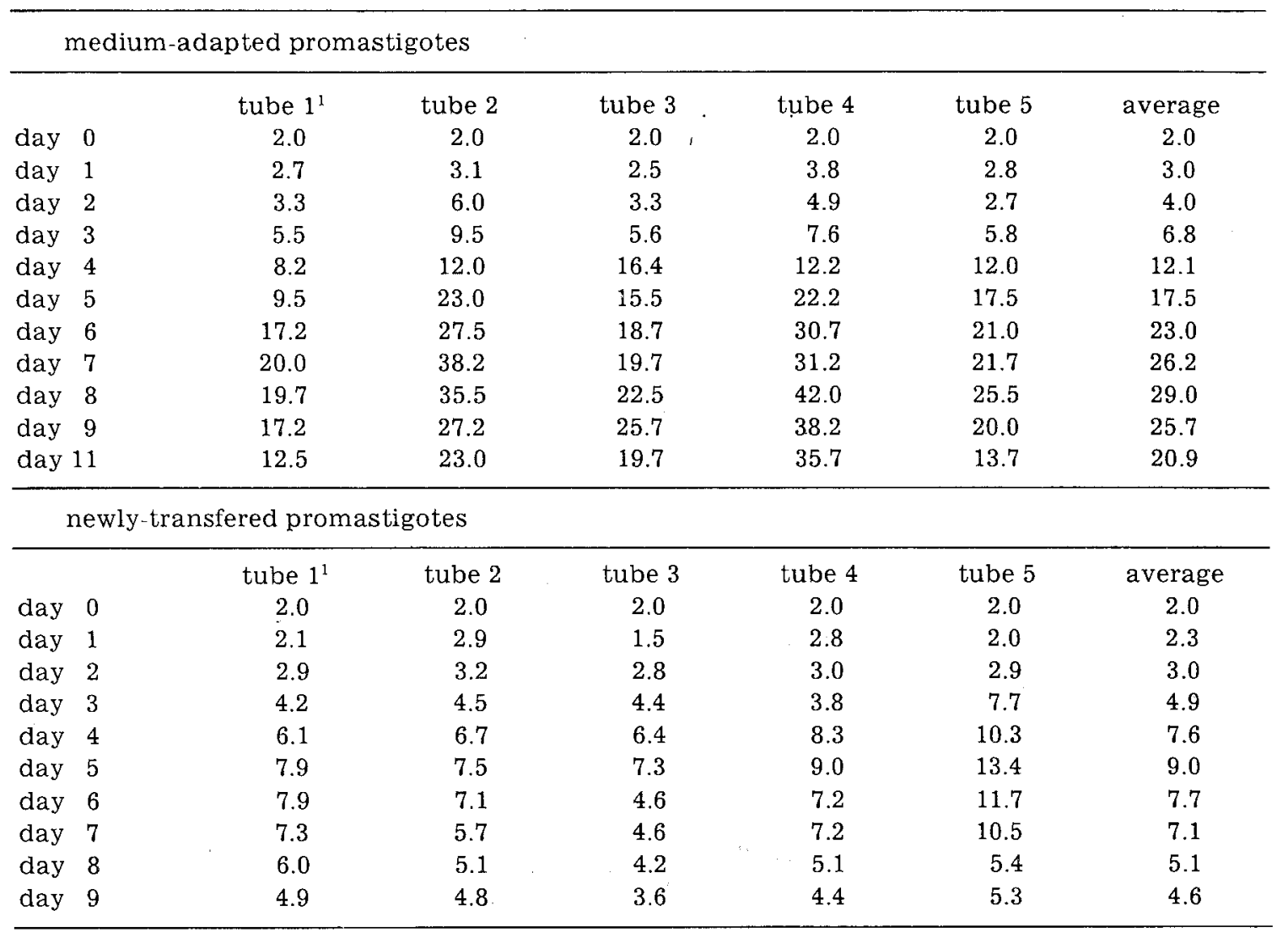

$1-\times 10^{6}$ cells.

TABLE 2

Titer variation of mucocutaneous leishmaniasis sera according to days in culture and adaptation to culture medium using $\mathbf{L}$. braziliensis braziliensis as antigen.

\begin{tabular}{|c|c|c|c|c|c|c|c|c|c|c|c|c|c|c|c|}
\hline \multirow{3}{*}{$\begin{array}{l}\text { cult. (days) } \\
\text { serum }\end{array}$} & \multicolumn{8}{|c|}{ medium adapted L.b.b. ${ }^{a}$} & \multicolumn{7}{|c|}{ newly transfered L.b.b. ${ }^{b}$} \\
\hline & & 0 & 2 & 4 & 5 & 6 & 7 & 9 & 0 & 2 & 3 & 4 & 5 & 6 & 9 \\
\hline & L.m..$^{\mathrm{c}}$ & & & & & & & & & & & & & & \\
\hline 1 & 160 & 20 & 40 & 20 & 80 & 80 & 40 & 0 & 320 & 80 & 160 & 40 & 80 & 10 & 0 \\
\hline 2 & 20 & 40 & 20 & 40 & 40 & 40 & 20 & 0 & 160 & 80 & 80 & 40 & 20 & 10 & 0 \\
\hline 3 & 40 & 0 & 0 & 0 & 0 & 0 & 0 & 0 & 20 & 0 & 10 & 10 & 10 & 0 & 0 \\
\hline 4 & 40 & 20 & 80 & 20 & 40 & 40 & 10 & 0 & 320 & 160 & 80 & 80 & 80 & 10 & 0 \\
\hline 5 & 160 & 20 & 20 & 80 & 40 & 40 & 20 & 0 & 80 & 40 & 80 & 40 & 40 & 0 & 0 \\
\hline
\end{tabular}

a -cells with 10 passages in Schneider's Drosophila medium supplemented with $20 \%$ fetal calf serum

b - cells cultured in SDM $+20 \%$ after transfer from biphasic medium

c - L. major-like titer. 
CELESTE, B. J. \& GUIMARÁES, M. C. S. - Growth curves of Leishmania braziliensis braziliensis promastigotes and surface antigen expression before and after adaptation to Schneider's drosophila medium as assessed by antiLeishmania human sera. Rev. Inst. Med. trop. Sáo Paulo, 30 (2): 63-67, 1988

\section{RESUMO}

Curvas de crescimento de promastigotas de Leishmania braziliensis braziliensis e expressáo de antígenos de superfície antes e depois da adaptação ao meio de drosófila de Schneider.

Promastigotas de Leishmania braziliensis braziliensis ( $M H o m / B R / 75 /$ M2903) foram cultivadas em meio de Schneider de cultura de drosófilas. Em um tipo de experiência as formas promastigotas já haviam sido previamente adaptadas ao meio por passagens consecutivas enquanto que no segundo as promastigotas foram cultivadas em meio bifásico e depois transferidas para o meio líqüido. o crescimento foi mais abundante nas células já adaptadas ao meio de cultura; células degeneradas e mortas, em pequenos números, estavam presentes desde o dia 5 para promastigotas adaptadas ao meio líqüido e desde o dia 3 para células recentemente adaptadas.

A síntese de antígenos de superfície diferiu de acordo com o modo como as células eram cultivadas, como verificado pelo título de 5 soros de leishmaniose mucocutânea. O melhor período para a preparação de antígenos de imunofluorescência foi considerado o dia 5 para promastigotas adaptadas ao meio de cultivo e o dia 3 para células recentemente adaptadas.

\section{ACKNOWLEDGEMENTS}

This paper was supported by PIDE VI, Conselho Nacional de Pesquisas Científicas e Tecnológicas (CNPq), and UNDP/World Bank/ Special
Programme for Research and Training in Tropical Diseases.

The authors thank Dr. M. C. Marzocchi for supplying the WHO-reference Leishmania strain.

\section{REFERENCES}

1. GUIMARÄES, M. C. S.; GIOVANNINI, V. L. \& CAMAR GO, M. E. - Antigenic standardization for mucocuta neous leishmaniasis immunofluorescence test. Rev. Inst. Med. trop. S. Paulo, 16: 145-148, 1974.

2. HINK, W. F. - Cell lines from invertebrates. In: J AKOBY W. B. \& PASTAN, I. H., ed. Methods in Enzymology. New York, Academic Press, 1979. v. 58, p. 450-466.

3. JAFFE, C. L.; GRIMALDI, G. \& MCMAHON-PRATT, D. - The cultivation anc. cloning of Leishmania. In: MOREL, C. M. ed. - Genes and antigens of parasites. $2 \mathrm{nd}$. ed. Rio de Janeiro, Fundaçăo Oswaldo Cruz, 1984. p. 47-92.

4. LAINSON, R. \& SHAW, J. J. - Las leishmanias y la leishmaniasis del Nuevo Mundo con particular referencia al Brasil. Bol. Ofic. sanit. panamer., 76: 93-114, 1974.

5. NICOLLE, C. H. - Culture du parasite du Bouton d'O. rient. C. R. Acad. Sci. (Paris), 146: 842-843, 1908.

6. NOVY, F. G. \& McNEAL, W. J. - On the cultivation of Trypanosoma brucei. J. infect. Dis., 1: 1-30, 1904.

7. PAPPAS, M. G.; McGREEVY, P. B.; HAJKOWSKI, R.; HENDRICKS, L. D.; OSTER, C. N. \& HOCKMEYER, W. T. - Evaluation of promastigote and amastigote antigens in the indirect fluorescent antibody test for American cutaneous leishmaniasis. Amer. J. trop. Med. Hyg., 32: $1260-1267,1983$.

8. SCHNEIDER, I. - Histology of larval eye-antennal disks and cephalic ganglia of Drosophile cultured in vitro. $\mathbf{J}$. Embryol. exp. Morph., 15: 271-279, 1966.

Recebido para publicação em 30/10/1987. 